\title{
Policy Initiation for Development of Slow Charging Station Infrastructure and E-rickshaw Vehicle Registration Process in India
}

\author{
Kishore Kumar Neelam
}

\section{ABSTRACT}

This paper is to enclave, a policy initiation for development of slow charging station infrastructure and E-rickshaw vehicles registration process in India. EV's (Electric Vehicles) as the new green nonpolluting vehicle for last mile connectivity within the city limits. At the E-rickshaw market a no of models available, but there is no study done for governing method, rules to follow and provision for charging infrastructure. $E$ rickshaw are being considered as a priority option towards sustainable development. These vehicles are the smart choice and encouraged as feeder system for last mile connectivity. E-rickshaw mode has been excluded from NMT (Non-motorized Transport) category and included in Motor Vehicles Act (2014) as special purpose battery operated vehicle. The main objective of the paper is to creating a space for building the charging infrastructure with different tariff and to setup governing rules for E-rickshaw operators.

Keywords: Electric Vehicles (EVs), E-rickshaw, Charging Point, Commuter, Operator, Operational Routes, E-rickshaw Parking, Night Halt.

Published Online: December 14, 2021

ISSN: $2736-5506$

DOI : $10.24018 /$ ejenergy.2021.1.5.28

\section{K. K. Neelam}

School of Planning and Architecture, SPA-New Delhi, India.

(e-mail: sukihyd2004@gmail.com)

\section{OBJeCtive OF THE STUdY}

Objective of the E-rickshaw study is to understand the base situation on-ground and creating a better infrastructure and governing rules. E-rickshaw mode has been excluded from NMT (Non-motorized Transport) category and included in Motor Vehicles Act (2014) as 'special purpose battery operated vehicle'. For E-rickshaw market to grow, the best practices from various states to be analyzed and policy framework are a setup with understanding the gaps and suggestion the recommendations for guiding success.

\section{INTRODUCTION OF E-RICKSHAW \& CURRENT SITUATION}

e-Rickshaws in a short span of time has multiplied its number and overcome the mode auto rickshaws, rickshaw pullers, due to its frequency, cost effectivity and its route coverage. These vehicles are environmentally friendly and provides employment opportunity to unskilled. For Erickshaw, at present there are no governing rules and regulations to monitor.

Non-standard models and locally assemble vehicles do not have any number plates, vehicle insurance and driving license, which led to increase in growth. E-rickshaw are creating most traffic congestion, no guided laws to govern them and no challan can be issued from traffic police. Erickshaws connectivity and service provides to shorter trips within a distance of $3 \mathrm{~km}$ range.
E-rickshaw has become a popular mode of transport for shorter trips. Major benefits of E-rickshaw are:

- Connectivity till last mile.

- Environmentally Friendly.

- Easy accessibility.

- Cost effective.

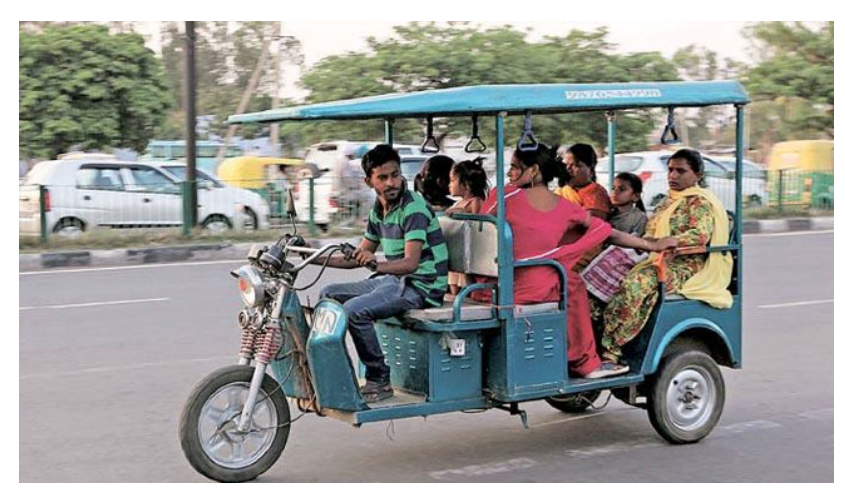

Fig. 1. A typical E-rickshaw with passengers plying on street.

\section{Methodology}

The research methodology involves a systematic process that focuses on objective and in additional collection of information for analysis. So, that the researcher can come to a conclusion. In this process, the study area is documented, reviewed with best practices and compared with other modes. 


\begin{tabular}{|c|c|}
\hline \multicolumn{2}{|c|}{ Identification of Need of Study } \\
\hline Stage 2 & \\
\hline \multicolumn{2}{|c|}{ Set-up Objective of Study } \\
\hline Stage 3 & \\
\hline $\begin{array}{ll}\text { Literat } \\
- & \mathrm{Na} \\
- & \mathrm{St} \\
- & \mathrm{Ty}\end{array}$ & $\begin{array}{l}\text { w } \\
\text { licies Initiatives } \\
\text { atory framework } \\
\text { arging Systems }\end{array}$ \\
\hline Stage 4 & \\
\hline \begin{tabular}{ll}
\multicolumn{2}{l}{ Secon } \\
- & $\mathrm{Gu}$ \\
- & $\mathrm{Sp}$ \\
- & $\mathrm{Ba}$ \\
- & $\mathrm{Ve}$ \\
- & $\mathrm{Ve}$ \\
- & $\mathrm{AC}$
\end{tabular} & $\begin{array}{l}\text { Collection } \\
\text { for E-rickshaw } \\
\text { n of E-rickshaw } \\
\text { e used } \\
\text { istration system } \\
\text { urance Policy } \\
\text { ta }\end{array}$ \\
\hline
\end{tabular}

Fig. 2. Study methodology for E-Rickshaw.

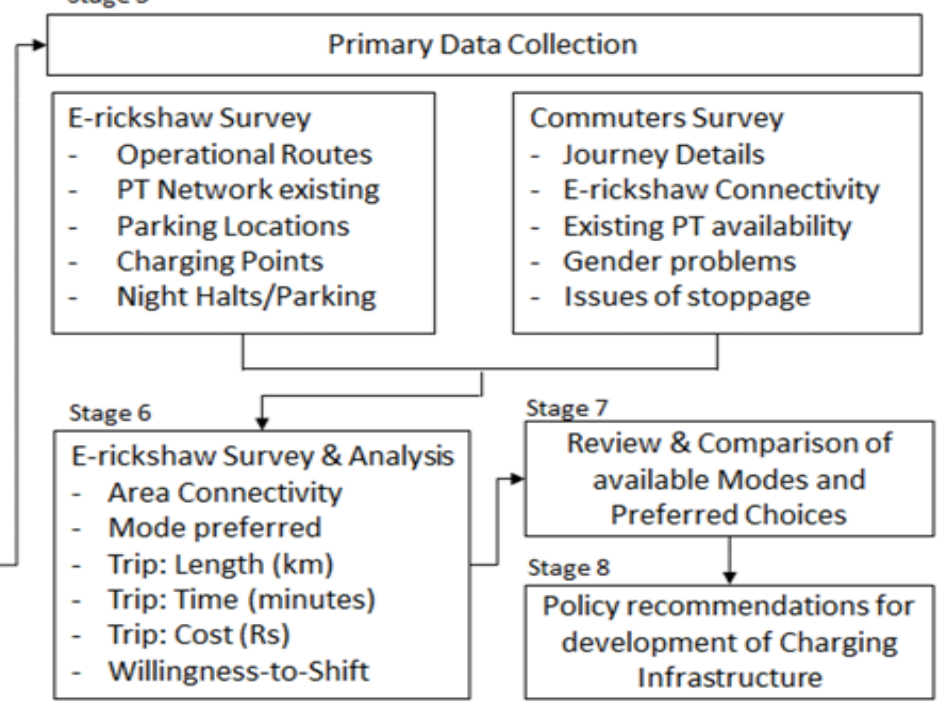

\section{A. Stage 1}

In the first stage, identification for need of the study and to develop a research-oriented objective.

\section{B. Stage 2}

The research area to be identified, some knowledge or information that is needed, it serves as the focus for further study process.

\section{Stage 3}

Literature review is usually the stage, which focus on the wide range of relevant literature information related to the data sources such as policy level information, books, journals, online articles etc. This stage provides foundation and knowledge about the research objectives. The information collected during this stage understand and identifies the future strategy.

\section{Stage 4}

Secondary data collection method need to be selected on the basis of data associated with several alternative methods. The knowledge gained through the review of literature guides the research in clarifying the research project.

\section{E. Stage 5}

Primary data collection needs to be preceded by a level of preparation and pilot data collection may be required in the form of survey questionnaires and through physical observations. The actual study begins with the collection of survey data.

\section{F. Stage 6}

Analysis of the survey data plays an important role in the achievement of research objectives. Data analysis method vary between secondary and primary studies. The results of these analysis are then reviewed and summarized. Then, the data will be analyzed to determine, the results of the study also provide valuable information.

\section{G. Stage 7}

All the time, effort and resources dedicated to are review and comparison of available modes and preferred choices are analyzed.

\section{H. Stage 8}

In the final stage, conclusions with policy recommendations relate to the level of achievement. It is also needed to cover study research limitations and suggestions.

\section{National LeVel Policy Initiatives for E- RICKSHAW}

\section{A. Motor Vehicle Act, 2014}

Motor Vehicles (Amendment) Act, E-rickshaw were categorized as a separate category of vehicles and defined as three-wheel vehicle used to carry passengers and limited power up to 2000 watts.

\section{B. FAME India Scheme}

Faster Adoption of Hybrid Electric Vehicles (FAME) was announced by the Government of India to be implemented in phases. This scheme provides subsidy for promoting electric vehicles in India. In FAME-I Scheme, it aimed at market creation through incentives across segments of vehicles. It provided subsidy on the purchase of E-rickshaws. FAME-II Scheme are sanctioned for setting up charging stations. It aims to support vehicles of all categories; 5 lakhs support is allocated for 3 wheelers to be used as public transport modes or registered as commercial vehicles.

\section{Smart City Mission (SCM)}

Under the Smart City proposal, the urban local authorities have planned to launch E-rickshaws as an aid for improving the livelihood. Financing for e-rickshaw purchase and deployment were included in Smart City Proposal (SCPs) report. The E-rickshaw can run at a speed of $25 \mathrm{kmph}$ with very less maintenance and promote environmentally friendly mode of transport and improve the last mile connectivity in the city. Customized finance schemes for E-Rickshaws shall be introduced with the support and guarantee of the government aimed at promoting electric vehicles. 


\section{State LeVel Initiatives for E-Rickshaw}

\section{A. Delhi E-rickshaw Policy}

1) E-Rickshaw Sewa Scheme: The scheme stated that vehicles bought before 2014 can get a certificate of road-worthiness from their manufacturer or registered e-rickshaw association. This scheme allows plying of e-rickshaws in NCT of Delhi after compiling with mentioned conditions the same. This scheme also includes permit conditions.

2) Subsidy scheme: Government of Delhi launched subsidy scheme. It provides INR 15,000 subsidy to owners of e-rickshaw whose vehicle are purchased before 2016 and INR 30000 for e-rickshaws purchased after 2016. INR 6,000 subsidy is provided by the Delhi Pollution Control Committee.

3) Domestic Charging: Delhi government stated that domestic charging of e-rickshaws is legal and the drivers can charge their rickshaws at home. Separate tariff category has been created for charging station for e-rickshaws with a flat rate of INR 5.50/KWh.

4) Delhi Electric Vehicle Policy: Government of Delhi approved 'Delhi Electric Vehicles policy', the primary objective of the policy was to reduce the emissions from transport sector through rapid adoption of battery vehicles (BEVs) and further contributing to $25 \%$ of new vehicle registrations by 2023 .

5) Charging Stations: Ministry of Power and Government of Delhi approved the plan for setting up 131 new EV charging stations (33 EV chargers at metro stations, 34 at CNG filling stations and 48 at Oil filling stations outlets).

\section{B. Telangana E-rickshaw Policy}

Telangana Electric Vehicle policy was introduced, and the objective is to achieve $100 \%$ shift to EVs by 2030 in the state and is supported by infrastructure and local manufacturing base for EVs and its components. This includes permission of e-rickshaws to operate in fringe areas, retrofitting rule for existing vehicles and permission for corporate ownership of manufacturing industries.

\section{Vehicle Registration Process of E-Rickshaw}

The following method are the currently practiced for the Erickshaw registration process at RTO office are explained in stage-wise

\section{A. Stage 1: Operator Selection \& Purchase}

In the very first stage, the operator selects the E-rickshaw with certain specifications, which includes the battery type. The operator has 2 options for the payment mode for the purchase with valid identifications.

\section{B. Stage 2: Vehicle Insurance}

Dealer provides the documents at the time of purchasing for vehicle fitness certificate, purchase copy and other relevant documents. The vehicle insurance is valid for 1 year duration with coverage in case of damages or an accident, etc.

\section{Stage 3: RTO Registration System}

The process starts at RTO office, as the E-rickshaw is registered in the separate category. The operator is then digitally signed with submitting valid proof including the driving license, vehicle insurance certificate and others. The vehicle gets temporary registered number plate and after one week of duration a permanent vehicle registration number in green plate is provided.

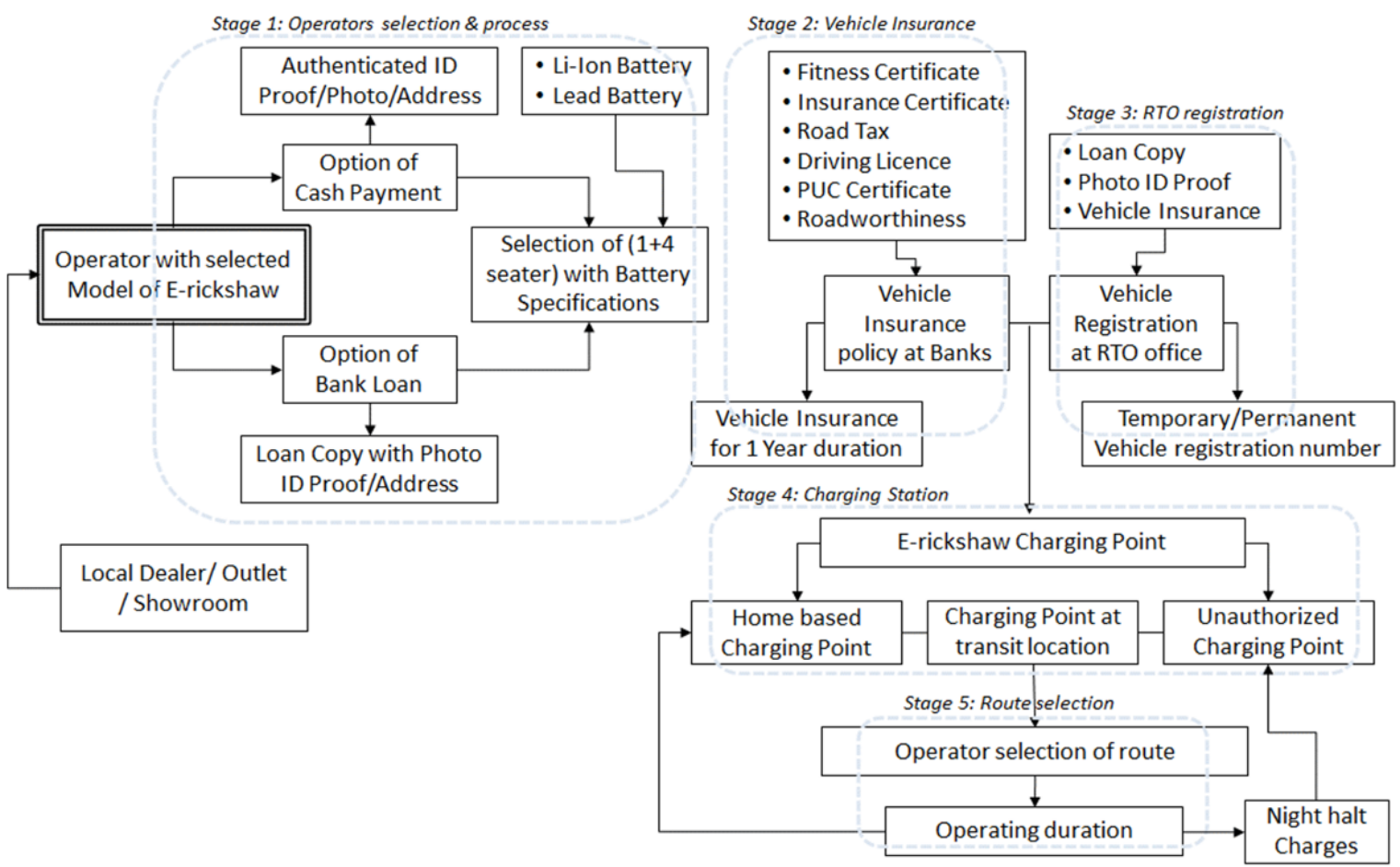

Fig. 3. Vehicle registration process of E-rickshaw. 


\section{Stage 4: Charging Station}

E-rickshaw operator has choice for charging point at homebase, transit location or unauthorized charging point. The operator choice makes them to avail the difference in the charging tariff system. At unauthorized charging point, the operator is imposed with night halt charges with parking space.

\section{E. Stage 5: Route Selection}

In the final stage, the operator will select the most demanded route with observations and longest route. After the day long operational services by the operator, the Erickshaw will go back to the charging point for next day schedule.

\section{EV Charging Station SPECIFICATIONS}

Public Charging Stations and Home-based Charging Points for EVs are the major hindrances in the propagation of these type of vehicles. Several business models for EV charging stations are present and functioning across the globe are-

\section{A. Home based Charging Point}

Home based Charging Point is the most effectively utilized and available method. The benefits of home-based charging point are it reduces queuing lines, it is cost-effective as the source of charging point is at operators' residence, no nighttime parking charges or theft.

\section{B. Battery Swapping Station}

Battery swapping stations is an idea for a defined area, that when a discharged vehicle needs an alternative fully charged battery within a short duration of time and replaced manually into the vehicle.

\section{Public Charging Station}

Public Charging Station (PCS) minimum requirement as per MoP (Ministry of Power) Guidelines are $13.5 \times 5.5 \mathrm{~m}$. EV's as a feasible option for distance trips with adequate availability of public charging station in the regional level to facilitate for refueling, recharging. The types of public charging stations, which are practiced world-wide are mentioned in Table I with different categories.

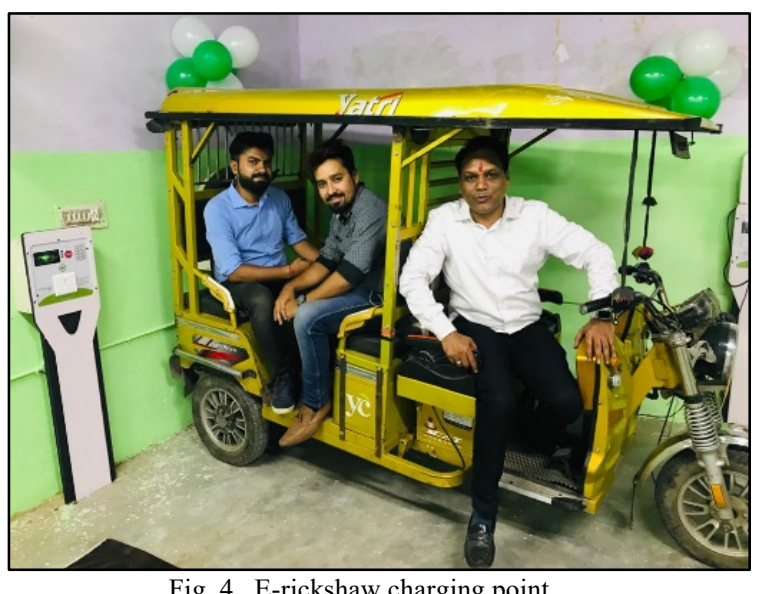

Fig. 4. E-rickshaw charging point.
TABLE I: TYPE OF PUBLIC CHARGING STATION (PCS)

\begin{tabular}{|c|c|c|c|}
\hline $\begin{array}{l}\text { S1 } \\
\text { No }\end{array}$ & $\begin{array}{c}\text { PCS: } \\
\text { Category } 1\end{array}$ & $\begin{array}{c}\text { PCS: } \\
\text { Category } 2\end{array}$ & $\begin{array}{c}\text { PCS: Fast Charging } \\
\text { Category } 3\end{array}$ \\
\hline 1 & $\begin{array}{l}\text { Category-1 type } \\
\text { falls under slow } \\
\text { charging point, } \\
\text { mostly practiced } \\
\text { all over. }\end{array}$ & $\begin{array}{l}\text { Category-2 type } \\
\text { comes under } \\
\text { medium charging } \\
\text { category. }\end{array}$ & $\begin{array}{c}\text { Category- } 3 \text { is the } \\
\text { fastest charging type } \\
\text { practiced. }\end{array}$ \\
\hline 2 & $\begin{array}{l}\text { Current type AC, } \\
\text { charging time } \\
\text { take about } 8-10 \\
\text { hours for full } \\
\text { charging. }\end{array}$ & $\begin{array}{l}\text { Current type AC, } \\
\text { it takes about 3-4 } \\
\text { hours for full } \\
\text { charge. }\end{array}$ & $\begin{array}{l}\text { Current type DC, the } \\
\text { charging times takes } \\
\text { around } 30-40 \text { minutes } \\
\text { and the practice is very } \\
\text { expensive. }\end{array}$ \\
\hline 3 & $\begin{array}{l}\text { Battery life is } \\
\text { longer and } \\
\text { durable with this } \\
\text { type. }\end{array}$ & $\begin{array}{c}\text { Battery life is } \\
\text { comparatively } \\
\text { durable and long } \\
\text { range. }\end{array}$ & $\begin{array}{l}\text { Battery life of faster } \\
\text { charging, which impact } \\
\text { on battery life in the } \\
\text { long duration. }\end{array}$ \\
\hline
\end{tabular}

Overall, the public charging stations operating presently take long time to recharge full batterie and it takes around 8 to 10 hours. EV Industry is still in its developing phase, as far as charging infrastructure is concerned and there are very few best practice models which are sustained.

\section{E-RICKSHAW COMPARISON WITH OTHER MODES}

In comparison to E-rickshaw with other modes in different parameters are briefly explained. The establishment of Erickshaw took very short span of time to evolve into an unauthorized manner.

\begin{tabular}{|c|c|c|c|}
\hline Parameters & E-rickshaw & Auto Rickshaw & $\begin{array}{c}\text { Cycle } \\
\text { Rickshaw }\end{array}$ \\
\hline Cost (Rs): & $80,000-1,10,000$ & $2,50,000$ & $\begin{array}{c}15,000- \\
30,000\end{array}$ \\
\hline $\begin{array}{c}\text { Seating } \\
\text { Capacity: }\end{array}$ & $4+1^{*}$ & $3+1 *$ & $2+1 *$ \\
\hline $\begin{array}{c}\text { Registration } \\
\text { Process: }\end{array}$ & $\begin{array}{l}\text { Registration is } \\
\text { mandatory under } \\
\text { Motor Vehicle } \\
\text { Act }\end{array}$ & $\begin{array}{l}\text { Auto rickshaw } \\
\text { comes under the } \\
\text { Motor Vehicle } \\
\text { Act, } 1988\end{array}$ & $\begin{array}{l}\text { No } \\
\text { Registration is } \\
\text { required }\end{array}$ \\
\hline $\begin{array}{c}\text { Fare } \\
\text { Collections in } \\
\text { Rs } / \mathrm{km}:\end{array}$ & $\begin{array}{l}\text { Charge Rs } 10 \text { for } \\
\text { a distance } \\
\text { between } 2-5 \mathrm{~km}\end{array}$ & $\begin{array}{c}\text { Rs } 25 \text { for first } 2 \\
\text { km, Rs } 8 \text { for } \\
\text { extra addition } \\
\text { km }\end{array}$ & $\begin{array}{c}\text { Charges Rs } \\
20 \text { for } 1-2 \mathrm{~km}\end{array}$ \\
\hline Speed: & $\begin{array}{c}\text { Most of these } \\
\text { vehicles travel at } \\
\text { a speed between } \\
20 \text { to } 35 \mathrm{kmph}\end{array}$ & $\begin{array}{c}\text { Maximum } \\
\text { speed of 60-70 } \\
\text { kmph }\end{array}$ & $\begin{array}{c}\text { Limited speed } \\
\text { less than } 20 \\
\text { kmph. }\end{array}$ \\
\hline $\begin{array}{c}\text { Fare } \\
\text { Collections in } \\
\text { Rs/km: }\end{array}$ & $\begin{array}{c}\text { Charge Rs } 10 \text { for } \\
\text { a distance } \\
\text { between } 2-5 \mathrm{~km}\end{array}$ & $\begin{array}{c}\text { Rs } 25 \text { for first } 2 \\
\text { km, Rs } 8 \text { for } \\
\text { extra addition } \\
\text { km }\end{array}$ & $\begin{array}{c}\text { Charges Rs } \\
20 \text { for } 1-2 \mathrm{~km}\end{array}$ \\
\hline $\begin{array}{c}\text { Maximum } \\
\text { Distance travel } \\
\text { per day: }\end{array}$ & $80-100 \mathrm{~km} /$ day & $\begin{array}{l}230-250 \\
\mathrm{~km} / \text { day }\end{array}$ & $15-25 \mathrm{~km} /$ day \\
\hline $\begin{array}{c}\text { Charging Time: } \\
\text { Electricity } \\
\text { Consumed: }\end{array}$ & $\begin{array}{c}\text { 6-8 hours/charge } \\
\text { 6-7 units/day }\end{array}$ & - & - \\
\hline
\end{tabular}

\section{SWOT ANALYSIS ON E-RICKSHAw ESTABLISHMENT}

\section{A. Strengths of E-rickshaw}

- E-rickshaw are non-pollution vehicles with green plate and environment friendly vehicles.

- With the clean energy, it reduces the impact on energy import bills. 
- E-rickshaws provides short distance feeder connectivity to the main line-haul.

- The frequency of these vehicles are very high and low fares for short distance trips

- E-rickshaws provides huge opportunity for untrained people at ground level operation routes to vehicle charging system and maintain.

- E-rickshaw provides pleasant drive with no noise and services at doorstep.

\section{B. Weakness with E-rickshaw}

- E-rickshaw mode has been excluded from NMT (Non-motorized Transport) category and included in Motor Vehicles Act (2014) as special purpose battery operated vehicle.

- Only approved models are registered at RTO (Road Transport Office) and non-standard models (i.e., locally assembled vehicles) are not registered and don't have vehicle number plate.

- Untrained operators, which leading to traffic congestion, on-street parking, unruly driving skills, irresponsible behavior with commuters and bystanders and not obeying the traffic rules.

- Non-standard models are used to assemble the parts of E-rickshaw with reused lead battery, which put risk to the commuters. No safety precisions are maintained while driving at the road.

- Presently, most of the E-rickshaw are practicing the slow charging method at residence with domestic connection and tariff. This put more load on the distribution Transformers and creating over-loading.

- At present condition, E-rickshaw are not following any rules and no regular norms from government to guide them.

\section{Opportunity with E-rickshaw}

- It will be an alternative source of fuel like renewables and reduced dependence on fossil fuels.

- It will support in building future EV market and charging stations.

- These E-rickshaws are reliable mode and cheaper in fares for commuters

- Lack of charging station infrastructure for these vehicles

- Lead based batteries replacement is expensive.

D. Threats with E-rickshaw

- E-rickshaw create most traffic congestion, no guided laws to govern them and no challan can be issued from traffic police.

- Unassembled and nonstandard models are entered into the market for distribution to operators.

- No statistical records on number of E-rickshaw sold and which are operational stage within the cities.

- Disposal of used lead acid battery creates hazard and environmental sensitive issues.

- Reuse or reprocessed battery can be threat to commuters and can be exploded at the time of charging.

\section{ReCOMmendation to Better Fit the E-Rickshaw}

EV share in Indian market is still being in developing stage and at the state level, policy initiatives and institutional setup has been created. In continuation, central and state government and respective authorities have to regulate a note with best practices on policies to be adopted for governing, regulating and creating infrastructure for sustaining this industry.

1) As per the Motor Vehicle Act, only standard models should be registered to ply on routes and with green number plate to be issued. These vehicles should be registered with separate category and registration certificate should be displayed on the vehicle.

2) Operators should and must have driving license as mandatory, it should also be displayed on the vehicle.

3) At the time of accident, commuter can also claim for the accidental insurance with any proof of the incident.

4) Mostly these E-rickshaw ply to the city centers, bus stands and railway stations so, at these locations and with following the guidelines by creating the charging infrastructure with less traffic rates. So, that these operators can shift from home-based charging to dedicated charging areas.

5) Lead acid batteries should be replaced with lithiumion batteries. No recycling and reprocess of lead acid batteries to be used. Government has to provide subsides for lithium batteries.

6) Best practices on E-rickshaw practices have to be followed by all state government. These vehicles are to be organize as main a feeder system.

\section{REFERENCES}

[1] Deepanjan M, Tushar J. Merits and challenges of e-rickshaw as an alternative form of public road transport system: a case study in the state of west Bengal in India. Energy Procedia. 2015;79: 307-314.

[2] Saiyad G, Minal, Kumar R, Rathwa D. Trips generated by rickshaw pullers and trip rate for cycle rickshaws: a case study of Delhi. Transportation Research Procedia. 2020; 48: 2296-2312.

[3] Cochrane C, Muner T, Fraser B. Design of an electrically powered rickshaw for use in India. Energies. 2019; 12: 3346.

[4] Rajvanshi AK. Electric and improved cycle rickshaw as a sustainable transport system for India. Current Science. 2002; 83(6): 25.

[5] Senthil V, Patel A, Hariharan M. Indian market analysis and sales strategy for potential electric racing vehicle segment. 2018;3(2).

[6] Chandran, N.; Brahmachari, S.K. Technology, knowledge and markets: connecting the dots-Electric rickshaw in India as a case study. J. Frugal Innov. 2015, 1, 2-10.

[7] Rajvanshi, A. K. (2002). Electric and improved cycle rickshaw as a sustainable transport system for India. Nimbkar Agricultural Research Institute (NARI). India: CURRENT SCIENCE.

[8] Harding S. The battery rickshaw crisis in New Delhi. Journal of Indian Law and Society. 2014; 6: 74.

[9] Draft Telangana Electric Vehicle Policy, 2019; Anjali Jaiswal, Charu Lata, "India Focus: Telangana Moves on Electric Mobility," NRDC, 2019 .

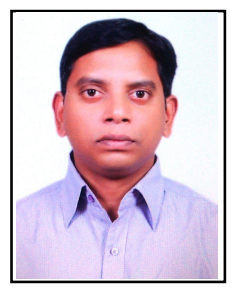

Kishore Kumar Neelam, Transport Planner from School of Planning and Architecture, New Delhi. Institutional Membership from ITPI-Institute of Town Planners India, New Delhi; IUT-Institute of Urban Transport, New Delhi; ASCI-Administrative Staff College of India, Hyderabad.

Work experience is providing technical assistance, project monitoring and project advisory support in the areas of Urban Transport, Smart Cities, Road Safety Audit studies, Detailed Project Reports \& Feasibility Studies, Traffic analysis \& Forecasting, Integrated Transit Corridor development and Street Network/Connectivity Plans, Green-field studies, BRTS \& Parking Studies. 